\title{
The Effects of a Discovery Learning Module on Geometry for Improving Students' Mathematical Reasoning Skills, Communication and Self-Confidence
}

\author{
Nur Choiro Siregar, Roslinda Rosli* and Siti Mistima Maat \\ The National University of Malaysia \\ Selangor, Malaysia
}

\begin{abstract}
The aim of the study was to examine the effectiveness of the Discovery Learning Module on Geometry (D-Geometry Module) in improving reasoning skills, communication, and self-confidence in mathematics among secondary school students. The research design was a quasi-experimental with a non-equivalent control group with pre-test and post-test design, where 128 students were grouped according to gender and the group of the intervention as well as a traditional group. Mathematical reasoning skills, communication, and self-confidence instruments were administered towards the students involved. Two-way MANOVA analysis showed that there was a main effect of the grouping. The finding showed that the integration of learning theories and discovery learning in Geometry could improve students' reasoning, mathematical communication, and self-confidence. Students' engagement is more dominant through the Discovery Learning Module rather than traditional learning. Therefore, the D-Geometry module should be used as a teaching resource for teachers, students, and curriculum-2013 (K-13) to facilitate classroom instruction.
\end{abstract}

Keywords: Discovery learning; Reasoning; Communication; Selfconfidence; Geometry

\section{Introduction}

Success in education is highly dependent on teachers as facilitators in delivering learning materials. Besides, other factors of success are derived from the content taught by teachers (Fyfe \& Brown, 2020; Martin \& Towers, 2015). According to Bier, Sherblom, Berkowitz, and Coulter (2016), learning mathematic improves, and confidence. Besides, mathematical education should be able to create students who can apply mathematical concepts in their daily lives (Hansen, 2020). However, most of the mathematics learning process that takes place in Indonesia

*Corresponding author: Roslinda Rosli, Email: roslinda@ukm.edu.my 
inclines on mastering mathematical principles and lacks the connection between mathematical lessons and daily life, which leads to the lack of emphasis on thinking, communicates mathematically, and thinks mathematically (Siregar, Rosli \& Maat, 2019).

Mathematical reasoning skills, communication, and self-confidence are aspects that students need to consider in the T\&L mathematic process. Reasoning skills are widely used in mathematics and one of the basics for success in other disciplines and the basis for developing students' cognitive aspects (Barnes, 2019; Dumas, Alexander \& Grossnickle, 2013). On another note, mathematical communication is a significant part of the mathematical learning process because, through mathematical communication, students can explain and expand their understanding and link between mathematical solutions and the arguments that they studied (Tabach \& Nachlieli, 2016). However, the results of previous studies found out that math communication skills are not effectively implemented by teachers. Therefore, the students are less likely to ask teachers questions if there are unclear questions about topics (Goldhaber, Krieg \& Theobald, 2020; Ryve, Nilsson \& Pettersson, 2013).

Teachers also said that students' mathematical values were still low due to their low self-confidence, especially when expressing their opinions, as they did not believe in the skills they had. Students' self-confidence was strongly influenced by students' internal factors (Julaihi, Ying, Li \& Bakri, 2020; Kleitman, Stankov, Allwood, Young \& Mak, 2012). Students who find themselves weak in math subjects have low self-confidence and often lack the skills needed to complete math tasks. Besides, the findings of Kleitman and Gibson (2011) show that students' self-confidence is positively related to their mathematical reasoning and communication.

One of the most challenging topics for many students is geometry (Adolphus, 2011; Suantoa, Zakaria \& Maat, 2019). Geometry is a topic learned from elementary school through secondary school. The subjects studied are cube, prism, and pyramid that was taught in their secondary school in the second semester. The geometry topic is the mathematical subjects that students were challenging to understand (Hua, Tang, Sun \& Han, 2019). The difficulty of understanding students in the topic of geometry lies in the basic concepts and the application of formulas in solving problems (Fonna \& Mursalin, 2019). Students are not allowed to practice reasoning, which makes them find it difficult to answer complex questions and to propose solutions to mathematical problems. At the same time, the constructivism theory also emphasizes meaningful teaching that involves students of the teaching and learning (T\&L) process. Some experts encourage mathematical reasoning to be incorporated into the school curriculum as it is widely used during the T\&L process (Dumas et al., 2013; Edson, Phillips, Slanger-Grant \& Stewart, 2018). Therefore, given that students' mathematical reasoning, self-confidence, and communication aspects play a critical role in learning mathematical, researchers expect that skills should be embedded in the T\&L process (Bier et al., 2016). 
Learning approaches that can improve student reasoning during the T\&L process at school are needed. There have been many teaching approaches to enhance students' quality in mathematics, including discovery learning. Discovery learning is essential because it could help students to solve problems and make mathematical conclusions, generate meaningful knowledge for students, actively engage students in T\&L, help process information to long-term memory levels (Darkis, 2020). The general objective of this research is to examine of discovery module geometry effect to improve secondary school students' mathematical reasoning skills, communication, and self-confidence. This study attempts to answer the following questions :

a) To what extend is there an impact of a discovery learning module on geometry towards students' mathematical reasoning by group and gender?

(b) To what extend is there an impact of a discovery learning module on geometry towards student mathematical communication by group and gender?

(c) To what extend is there an impact of a discovery learning module on geometry towards students' self-confidence by group and gender?

The research hypotheses are

(a) $\mathrm{H}_{01}$ : There were no differences in mean scores of students' mathematical reasoning by group and gender;

(b) $\mathrm{H}_{02}$ : There were no differences in mean scores of students' mathematical communication by group and gender;

(c $\mathrm{H}_{03}$ : There were no differences in mean scores of students' mathematical selfconfidence by group and gender.

\subsection{Review of Literature}

Curriculum-2013

Curriculum 2013 (K-13) is a construct that integrates two major frameworks of student's competence and character (Wachidi, Rodgers \& Tumanov, 2020). The learning process implemented in K-13 is through a scientific approach. Scientific approaches enable students to "discover" new knowledge through experimentation (Ginting, Joebagio \& Si, 2020). Therefore, this approach has a significant relationship to the goal of education. The current curriculum situation in Indonesia requires student engagement and active in the T\&L. One of the learning approaches adopted by Curriculum-2013 is to use the discovery approach. Through a discovery approach, it is believed that a learning environment that contributes to student activities in the T\&L process will emerge. One of the strengths of discovery learning is the model of learning in the educational world, as this approach trains students to construct knowledge during the learning process (Shofiyati, Retnoningsih \& Ridlo, 2020).

\section{Mathematical Reasoning Skills}

Reasoning during the learning of mathematics can foster students' cognitive skills in making mathematical hypotheses and thinking logically (Kılıç \& Sağlam, 2013). Reasoning ability is a benchmark of student intelligence that cannot be separated from mathematical learning (Mayer, Sodian, Koerber \& Schwippert, 2014). Reasoning ability guides students to understand mathematics topic more deeply and is a cornerstone of success in other subjects (Kılıç \& Sağlam, 2013). The principle of mathematical reasoning is to train students to relate one context of 
mathematics topic to another during the T\&L process. The aspects that can develop students' mathematical reasoning skills are the aspects that can improve students' mathematical reasoning skills are the process of identifying patterns, hypothesizing, supportive arguments, and evaluating conclusions (Otten, Gilbertson, Males \& Clark, 2014). According to Ferguson, Maloney, Fugelsang, and Risko (2015), low students' mathematical reasoning will influence students to have high levels of math anxiety that, in which case would lead to their mathematical learning ability, does not exist. Experts recommend that mathematical reasoning be incorporated into the school curriculum and implemented in the T\&L process (Kaufmann, 2019). Therefore, learning approaches and the role of teachers is crucial for developing student reasoning during the T\&L process.

\section{Mathematical Communication}

Mathematical communication is a vital part of the learning process (Diez-Palomar \& Olive, 2015). Developing mathematical communication skills require specific standards that students want to achieve. According to NCTM (2014), the standard aspects are: (a) organizing and integrating their mathematical thinking through communication, (b) communicating their mathematical thinking logically and either to teachers and other students, (c) analyzing and evaluating on the thinking-strategies of solving mathematics by others and (d) using mathematical language to convey mathematical ideas accurately. Through mathematical communication, students would be able to discuss ideas, value friends' opinions, expand their understanding, and the link between mathematical solutions and the arguments used (Tabach \& Nachlieli, 2016). The application of mathematical communication in the T\&L process can be critical and responsive (Diez-Palomar \& Olive, 2015). It is found that students are becoming less interested in asking difficult questions to teachers, while the students were needed the guidance of teachers to develop students' communication skills (Moschkovich, 2015).

\section{Self-Confidence}

Confidence in this context can be defined as faith in one's own ability to solve mathematic materials and problems (Stankov, Kleitman \& Jackson, 2015). However, the lack of self-confidence in mathematic subjects among students is higher than in other subjects (Stankov, Lee, Luo \& Hogan, 2012). Students' anxiety over mathematic subjects is one of the factors contributing to their low confidence (Kleitman \& Gibson, 2011). Low confidence among high school students is a problem that teachers pay less attention to. Be that as it may, if this condition is ignored, it will negatively impact the students' mathematical achievement in their future (Humble \& Dixon, 2017). Student mathematics achievement is influenced by the student's self-confidence (Kleitman et al., 2012).

\section{Impact of Gender}

Gender also influences students' mathematical reasoning, communication, and self-confidence. The results of previous studies show that male students are better in terms of mathematical reasoning, communication, and self-confidence than female students (Voyer, Voyer \& Saint-Aubin, 2017). There are differences between male and female students in the mathematical problem-solving process (Murhayati et al., 2019; Voyer et al., 2017). Furthermore, the overall self- 
confidence of female students has a negative average. However, some researchers have found that the differences between male and female students are relatively small in the mathematical learning process (Cho, 2017).

\section{Discovery Learning}

There have been many teaching approaches that tried to improve the quality of students in mathematics, including discovery-based approaches (Siregar et al., 2019). Discovery learning applied three theoretical learning in the T\&L process, such as cognitive, constructivism, and behaviorism (Siregar et al., 2019). Students' involvement in their exploration is the application theory of constructivism. The exploration process can actively affect students' cognitive processes. As a closing T\&L stage, each group tends to demonstrate the results of a mathematical solution as a form of their understanding and skills that they possess. The application of discovery learning ensures to improve intelligent and knowledgeable students. Students finding solutions to their problems will lead to the improvement of their self-confidence, communication skills, and academic achievement. This method emphasizes the constructions, cognitions, and practices that would be associated with their everyday life and, at the same time, ensures that the students have innovative skills (Cetin-Dindar, 2016). Through discovery learning, students would participate to the extent that they have a positive impact on developing critical thinking skills, analyzing, and interpreting information (Edwards, 2015; Majid \& Majid, 2018).

\section{Theoretical Framework}

The discovery learning module is developed on three learning theories, namely constructivism, cognitive, and behaviorism. The constructivism principles such as (a) student-generated knowledge, (b) student-centered learning process, (c) teacher role as facilitator, and (d) learning goals focused on non-final processes (Bakar, Mukhtar \& Khalid, 2019; Baroody, Clements \& Sarama, 2019). Whereas, cognitive learning theory relies on information processing theory and cognitive load theory. Cognitive theory plays a significant role in helping students understand mathematical reasoning, communication, and self-confidence. Cognitive aspects are strongly related to students' mental activity. These cognitive aspects comprise six stages, including (a) knowledge, (b) understanding, (c) application, (d) analysis, (e) synthesis, and (f) evaluation (Bloom, Engelhart, Furst, Hill \& Krathwohl, 1956). On the other hand, for behaviorism, learning is a change in behavior as a result of the relationship between stimulus and response that takes place in one's life (Morrison, Ross, Kalman \& Kemp, 2013). Through this module, students learn actively in constructing knowledge based on learning experiences (Von Glaserfield, 1989; Norton \& Alibali, 2018), and utilize their cognitive ability to solve various mathematical problems.

\section{Research Methodology}

\subsection{Research Design}

The design used in this quasi-experimental study was the pre-test and post-tests with non-equivalent groups. There are tests performed before the data were collected. The actual experiments were conducted and then presented with the results of the post-test (Rogers \& Révész, 2020). This design was conducted 
because, in this study, there were treatment classes and control classes (Cook, Campell \& Shadish, 2013). Measurements were collected at the same time for both experimental (discovery module) and control (traditional) groups. The method of data collection is through testing of three instruments, namely mathematical reasoning and communication test, and self-confident questionnaire. The test performed consists of several steps. Firstly, both groups (discovery module and traditional) were given a pre-test. Secondly, the implementation of learning use with the discovery module and traditional learning. The learning process and components of the discovery module are based on the section in 2.3. Traditional learning processes are (a) teachers conducting T\&L processes, students responding, and (b) teachers implementing assessments of students' responses (Luguetti, Aranda, Nuñez Enriquez \& Oliver, 2019). Lastly, both groups performed the post-tests.

\subsection{Participants}

The procedure for selecting respondents in the study was through purposive sampling for the chosen school. This technique is used to derive similarities from the sample, the quality of the study participants was in terms of knowledge and experience and the willingness of the participants to participate in the study (Cresswell \& Plano Clark, 2011). The study involved 128 students in grade VIII from secondary school (SMP) at Padangsidimpuan, Indonesia. The experimental group consisted of 22 males and 42 females, while the control group consisted of 24 males and 40 females. The justification for the selection of SMP as respondents in this study was due to (a) students from applying the K-13 with grade A and less than 1-2 years, (b) grade 8, (c) classes consisting of male and female, and (d) taught in geometry topics. Also, (e) the homogeneity of student groups in the classroom, (f) the teacher experience more than four years, and (g) good collaboration between teachers and school principals.

\subsection{Classroom Instruction}

There is a difference between the T\&L of the D-Geometry process and the traditional T\&L process in class. In the D-Geometry process, teachers will focus on four main components, such as (1) lesson plan, (2) teacher's book, (3) student book, and (4) the student activity sheet. Table 1 below showed the T\&L process in D-Geometry. The implementation of traditional learning was carried out as practiced in schools. Traditional learning methods are teaching methods that were either delivered by the teacher directly to the student or teacher-centered, and the T\&L process presented by the teacher was passive and memorable. In the traditional classroom, teachers will provide information related to the topic of geometry and give students time to solve questions in the textbook (Lessani, Yunus \& Burn, 2017). 
Table 1: The T\&L process in D-Geometry

\begin{tabular}{|c|c|c|}
\hline Question & $\begin{array}{l}\text { Steps of D- } \\
\text { Geometry }\end{array}$ & Students Activities \\
\hline \multirow{10}{*}{$\begin{array}{l}\text { A rectangular prism- } \\
\text { shaped swimming pool, } \\
\text { which base area is a } \\
\text { trapezium. It is known } \\
\text { that the size of the } \\
\text { trapezium is } 17 \mathrm{~m} \text {, and } \\
\text { the length of one side is } \\
\text { three times the length of } \\
\text { the other side. If the sum } \\
\text { of the two sides of the } \\
\text { same size is } 32 \mathrm{~m} \text { and the } \\
\text { depth of the pool is } 2 \mathrm{~m}, \\
\text { then (a) sketch the pool } \\
\text { and its dimensions; (b) } \\
\text { calculate the volume of } \\
\text { water needed to fill the } \\
\text { pool to the full. }\end{array}$} & First: Prerequisite & $\begin{array}{l}\text { Prerequisite topics are the process of } \\
\text { students' exploration and thinking } \\
\text { activity. }\end{array}$ \\
\hline & $\begin{array}{l}\text { Second: } \\
\text { Identifying } \\
\text { problems }\end{array}$ & $\begin{array}{l}\text { The process of identifying various } \\
\text { problems is one of the ways students } \\
\text { find solutions to the topics they are } \\
\text { learning. }\end{array}$ \\
\hline & $\begin{array}{l}\text { Third: } \\
\text { Planning and } \\
\text { collecting data }\end{array}$ & $\begin{array}{l}\text { Students can explore various sources } \\
\text { related to the topics. }\end{array}$ \\
\hline & $\begin{array}{l}\text { Fourth: } \\
\text { Analyzing data }\end{array}$ & $\begin{array}{l}\text { Students should analyze the data to } \\
\text { support the finding that they have } \\
\text { obtained. }\end{array}$ \\
\hline & $\begin{array}{l}\text { Fifth: } \\
\text { Processing data }\end{array}$ & $\begin{array}{l}\text { The data process is the result of a } \\
\text { combination of the first until the } \\
\text { fourth steps that the student has } \\
\text { taken. }\end{array}$ \\
\hline & $\begin{array}{l}\text { Sixth: } \\
\text { Planning solution }\end{array}$ & $\begin{array}{l}\text { The planning solution process is not } \\
\text { limited to specific forms of problem- } \\
\text { solving. Students can take many } \\
\text { forms as long as the answers they } \\
\text { make are correct and follow the } \\
\text { appropriate mathematical concepts. }\end{array}$ \\
\hline & $\begin{array}{l}\text { Seventh: } \\
\text { Argumentation }\end{array}$ & $\begin{array}{l}\text { The argumentation is one of the best } \\
\text { opportunities for students to share } \\
\text { different ideas and to build } \\
\text { knowledge. }\end{array}$ \\
\hline & $\begin{array}{l}\text { Eighth: } \\
\text { Assessing }\end{array}$ & $\begin{array}{l}\text { Identifying student errors and } \\
\text { making corrections based on } \\
\text { correcting analysis results are called } \\
\text { "assessing". }\end{array}$ \\
\hline & $\begin{array}{l}\text { Ninth: } \\
\text { Communicating }\end{array}$ & $\begin{array}{l}\text { Students finding presentations in the } \\
\text { classroom is one of the forms of } \\
\text { communication carried out. }\end{array}$ \\
\hline & $\begin{array}{l}\text { Tenth: } \\
\text { Concluding }\end{array}$ & $\begin{array}{l}\text { Students will make conclusions and } \\
\text { receive feedback from the teacher. }\end{array}$ \\
\hline
\end{tabular}

\subsection{Data Collection, Analysis, and Tools}

The instruments consist of three parts to measure (a) reasoning, (b) mathematical communication, and (c) self-confidence. The mathematical reasoning and 
communication parts contain five subjective questions aimed at measuring students' mathematical reasoning and communication skills. The self-confidence part is developed to determine students' level of self-confidence in learning geometry using a Likert scale. The self-confidence instrument contains four constructs consisting of 26 items. Valid instruments facilitate researchers in obtaining correct, accurate, and reliable data. The inter-rater was calculated to present the item analysis on mathematical reasoning and communication. This study involved two teachers as inter-rater agreement or interrater reliability. Thirty-two students participated in the test that satisfies the requirement for Cohen's Kappa calculations (Bujang \& Baharum, 2017). Table 2 shows the analysis result of the mathematical reasoning and communication instruments.

Table 2: Reliability of mathematical reasoning and communication instruments

\begin{tabular}{|c|c|c|}
\hline Instrument & Kappa Index & Interpretation \\
\hline Mathematical Reasoning & 0.67 & Good agreement \\
\hline Mathematical Communication & 0.66 & Good agreement \\
\hline
\end{tabular}

The Kappa Index in Table 2 shows that mathematical reasoning and communication questions are in good agreement and can be used in the actual study, whereas the reliability coefficient of the self-confidence instrument indicates that the self-confidence item is in the "High" category with a Cronbach Alpha value of 0.86 . Therefore, all items are reliable for use during the study.

The data collected through this study were analyzed descriptively and inferentially using SPSS version 21.0 software. The inferential analysis is a statistical inference based on data. The analysis was performed with Two-Way Multivariate Analysis of Variance (MANOVA) because it had two factors, namely group (D-Geometry and traditional) and gender (male and female). In the MANOVA test, the independent variable is the factor (Pallant, 2016). The TwoWay MANOVA test contains at least two independent data categories. Two-way MANOVA was used to examine the effects on categorical variables (group and gender) simultaneously on the mean scores of students. The results of this analysis can provide information on students' mathematical reasoning, communication, and self-confidence, based on the interaction effect. When the results show that there is interaction, then it can be extended to see the "main effects" of each independent variable. Before conducting the Two-Way MANOVA test, there are underlying assumptions that must be satisfied. The first assumption is that the dependent variable is measured at a continuous level, in which the data are in the form of an interval or ratio scale of measurement (Aryadoust \& Raquel, 2019). Two categorical variables consist of two or more categories of categories (the second assumption).

Independent observation can be explained as there is no relationship between observations in each group, for the third assumption. The fourth assumption is to detect the value of outliers. According to Hair, Black, Babin, and Anderson (2010), when the sample size is $>80$, then observations with a $Z$ score of 3 or $<-3$ are extreme outliers. The fifth assumption is the test of normality. This stage is to see 
the normality of the distribution of reasoning test data, communication, and confidence among the groups compared then the severity test was conducted. The last assumption is the test of homogeneity. The Levene test was performed to determine the relative variability of the variance. The variance values of the dependent variables across all groups in the independent variables were similar. The distributions had identical variation based on $p$-values for equal variances assumed is higher than 0.05 (Pallant, 2016).

\section{Research Results and Discussion}

Descriptive statistics serve as a means of collecting data and presenting useful information. The mean values of the mathematical reasoning, communication, and self-confidence scores of the students who experienced T\&L using the DGeometry method are higher than that of students who experienced traditional learning methods. The mean values T\&L using D-Geometry method are higher than traditional learning methods in reasoning (male, $\min =79.31$ and female, $\min$ $=79.23$ ), communication (male, $\min =76.59$ and female, $\min =76.30$ ), and selfconfidence (male, $\min =81.40$ and female, $\min =81.40)$. Whereas, the value that students participated in the traditional learning process is the reasoning (male, $\min =53.59$ and female, $\min =53.50)$, communication $($ male, $\min =55.83$ and female, $\min =55.62$ ), and self-confidence (male, $\min =65.79$ and female, $\min =$ 65.57). Table 3 is the result of the Two-Way MANOVA test for all three variables according to group and gender.

Table 3: Results of the multivariate test for the post data

\begin{tabular}{|c|c|c|c|c|}
\hline Effect & Pillai's Trace & $\mathbf{F}$ & $\mathbf{F}_{\mathbf{0 . 0 5}(3,128)}$ & $\mathbf{p}$ \\
\hline Group & 0.57 & 54.82 & 2.68 & 0.000 \\
\hline Gender & 0.67 & 84.12 & 2.68 & 0.007 \\
\hline Group*Gender & 0.06 & 2.83 & 2.68 & 0.041 \\
\hline
\end{tabular}

The multivariate tests in Table 3 have shown that $p=0.041(p<0.05)$, which shows that there was a statistically significant interactional effect based on the group. There was no significant interactional effect between gender and group on dependent variable F $(3,128)=2.83, \mathrm{p}=.041$; Pillai's Trace $=.065$. Table 4 refers to the results of the test of between-subjects effects.

Table 4: Results of the test of between-subjects effects

\begin{tabular}{|c|l|c|c|c|}
\hline Effect & \multicolumn{1}{|c|}{ Dependent Variable } & df & F & p \\
\hline Group & Mathematical Reasoning & 1 & 43.63 & 0.00 \\
\hline & Mathematical Communication & 1 & 37.60 & 0.00 \\
\hline & Self-confidence & 1 & 67.77 & 0.00 \\
\hline Gender & Mathematical Reasoning & 1 & 8.11 & 0.07 \\
\hline
\end{tabular}




\begin{tabular}{|l|l|c|c|c|}
\hline & Mathematical Communication & 1 & 16.24 & 0.09 \\
\hline & Self-confidence & 1 & 0.69 & 0.40 \\
\hline Group*Gender & Mathematical Reasoning & 1 & 5.20 & 0.12 \\
\hline & Mathematical Communication & 1 & 1.10 & 0.29 \\
\hline & Self-confidence & 1 & 2.12 & 0.14 \\
\hline
\end{tabular}

Table 4 showed that there was a main effect of grouping on students' reasoning, communication, and self-confidence $\mathrm{F}(1,128)=43.63 ; 37.60 ; 67.77, \mathrm{p}<0.001$. Therefore, indicates that there are significant differences in students' reasoning, communication, and self-confidence between the control and experiment groups. Furthermore, there was no main effect of students' reasoning, communication, and self-confidence based on gender $\mathrm{F}(1,128)=8.11 ; 16.24 ; 0.69, \mathrm{p}<0.05$ and group* ${ }^{*}$ gender $\mathrm{F}(1,128)=5.20 ; 1.10 ; 2.12, \mathrm{p}<0.05$.

\subsection{Effects of Learning Discovery Module and Traditional on Students}

Some of the positive impacts of using the D-Geometry module includes encouraging students to develop skills in assessing, analyzing, drawing conclusions, giving ideas, being creative, and thinking critically and actively. The type of questions in the student activity sheet that teachers create can foster reasoning, especially in terms of formulating mathematical solutions. The DGeometry Module can reduce anxiety and skepticism during the process of ideas exchange. Each group member works together in generating ideas and making excuses to find the best solution. This module helps students to link the mathematical theory studied with their previous knowledge (Siregar et al., 2019). Among the goals of mathematics education are aspects of mathematical communication (Tabach \& Nachlieli, 2016). The impact of the D-Geometry Module on students' mathematical communication can be seen through (1) using mathematical vocabulary, (2) improving understanding and thinking processes, and (3) connecting between mathematical concepts (Kosko \& Gao, 2015; Tabach \& Nachlieli, 2016). In-module questions encourage the active participation of students in building knowledge to enhance their mathematical communication and self-confidence. The principle of learning with the D-Geometry Module is that teachers allow students to discover their problems in different ways. Each group has the opportunity to present their work in front of all students, which will encourage and foster their confidence (Charalambous, 2015). Students' selfconfidence positively affects their math skills (Bates, Kim, \& Latham, 2011).

This module implements active participation between male and female students. Therefore, there was no difference between male and female students for mathematical reasoning, communication, and self-confidence levels. The result of this study fits the conclusion of previous studies, in the case that it was inferred that gender does not affect the students' mathematical reasoning, communication, and self-confidence (Lauer \& Lourenco, 2016). The result exists because male students and female students had the same experience in T\&L. On another note, both the male and female students have the assumption that mathematic is a 
strenuous subject (Wolfe, 2019). However, there are differences in the T\&L process in schools that have traditionally adopted learning methods. In a typical mathematics classroom, there is no active involvement of students in learning. Utilizing a learning method with active student engagement has more positive effects on learning outcomes than traditional (Borko, 2019). The traditional teaching approach, usually a teacher provides information to students and is not allowed to present ideas during the learning process. The teachers are active in giving information about geometry without the active participation of students. So, students are good at memorizing geometry concepts without understanding concepts. Besides, students study individually without engaging the group. Classroom centered around the teacher and each student sitting behind a separate desk (Naseri, 2019).

\section{Conclusion}

A learning process that promotes active engagement among students can create effective learning of skills in any subject area. Among the skills that the students gained is fostering high-level thinking, creativity, and innovation. Teachers need to take into account the teaching methods that students need to achieve their learning goals. The T\&L process implemented in the D-Geometry Module is direct engagement through learning in small groups. Group learning can overcome students' anxiety to learn mathematics. Also, this module encourages students to undertake the construction of existing knowledge in mathematical T\&L. The results of the T\&L with the D-Geometry Module have significant differences in the aspect of mathematic scores. The scores of the students who experienced learning with the module are higher than the scores of the students experiencing traditional learning. For all three study variables, it was found that male students' scores were the same as female students. The D-Geometry Module has a positive impact on students' mathematical reasoning, communication, and selfconfidence. Therefore, this module is one of the alternative ways that teachers and policymakers can utilize in the future. The implementation of the D-Geometry Module in the process of learning mathematics is appropriate with the objectives of K-13.

\section{Recommendation}

Future studies are recommended to use more participants from different regions in Indonesia and increase the duration of the study to avoid bias in the study results. In addition, future researchers are also advised to build more specific questions on student activity sheets and integrate a discovery learning approach into other difficult mathematics topics.

\section{Implication}

This study produced a discovery module on geometry topics in the form of learning plans, teacher books, student books, and student activity sheets. Therefore, this module can have implications for (a) learning theory, (b) mathematics T\&L practice, and (c) curriculum design of $\mathrm{K}-13$ on mathematics subjects. The learning theories of constructivism, cognitive, and behaviorism are implemented in this module. Teachers only have as a facilitator in the T\&L process. Therefore, the source of information that students gain is no base on 
teachers. Students should note the knowledge they have gained from various sources. The K-13 draftsman implies that geometry topics can be integrated with discovery methods to solve students' problems in learning mathematics.

\section{Limitation}

This study was conducted only for the secondary students (SMP) at Padangsidimpuan that implemented the K-13 based teaching process. The modules of the T\&L process only use the discovery learning approach. The discovery module is limited to geometry topics (cube, cube, prism, and pyramid). The duration of the study was included as short as 6 weeks.

\section{References}

Adolphus, T. (2011). Problem of teaching and learning of geometry in secondary schools in rivers state, Nigeria. International Journal of Emerging Science, 1(2), 143-152.

Aryadoust, V., \& Raquel, M. (2019). Quantitative data analysis for language assessment volume I: Fundamental techniques. London: Routledge.

Bakar, M. A., Mukhtar, M., \& Khalid, F. (2019). The development of a visual output approach for programming via the application of cognitive load theory and constructivism. (IJACSA) International Journal of Advanced Computer Science and Applications, 10(11), 305-312.

Barnes, A. (2019). Perseverance in mathematical reasoning: The role of children's conative focus in the productive interplay between cognition and affect. Research in Mathematics Education, 1-24. doi:10.1080/14794802.2019.1590229

Baroody, A. J., Clements, D. H., \& Sarama, J. (2019). Teaching and learning mathematics in early childhood programs. Handbook of Early Childhood Care and Education, 329354.

Bates, A. B., Kim, J., \& Latham, N. (2011). Linking pre-service teachers' mathematics selfefficacy and mathematics teaching efficacy to their mathematical performance. School Science and Mathematics, 111(7), 325-333.

Bier, M. C., Sherblom, S. A., Berkowitz, M. W., \& Coulter, B. (2016). The ways character strengths support K-8 mathematics and the common core state standards. Journal of Character Education, 12(1), 35-53.

Bloom, B. S., Engelhart, M. D., Furst, E. J., Hill, W. H., \& Krathwohl, D. R. (1956). The taxonomy of educational objectives the classification of educational goals, handbook: Cognitive domain. New York: David McKay.

Borko, H. (2019). Learning trajectories in mathematics professional development. Learning trajectories for teachers: Designing effective professional development for math instruction. New York: Teacher College Press.

Cetin-Dindar, A. (2016). Student motivation in constructivist learning environment. Eurasia Journal of Mathematics, Science \& Technology Education, 12(2). doi:10.12973/eurasia.2016.1399a

Charalambous, C. Y. (2015). Working at the intersection of teacher knowledge, teacher beliefs, and teaching practice: A multiple-case study. Journal of Mathematics Teacher Education, 18(5), 427-445. doi:10.1007/s10857-015-9318-7

Cho, S. Y. (2017). Gender and confidence-evidence from the PISA math test. Retrieved from Young\%20Cho.pdf

http://kea.ne.kr/conference-2017/download/S6-7-2_Seo-

Cook, T. D., Campbell, D. T., \& Shadish, W. (2013). Experimental and quasi-experimental designs for generalized causal inference. Boston, MA: Houghton Mifflin. 
Cresswell, J. W., \& Plano Clark, V. L. (2011). Designing and conducting mixed method research. Thousand Oaks, CA: Sage.

Darkis, J. M. (2020). Views and challenges in teaching mathematics of elementary teachers in rural and urban school districts. Journal of Critical Reviews, 7(4), 107-112. doi:10.31838/jcr.07.04.19

Diez-Palomar, J., \& Olive, J. C. (2015). Using dialogic talk to teach mathematics: The case of interactive groups. ZDM Mathematics Education, 47(7), 1299-1312. doi:10.1007/s11858-015-0728-x

Dumas, D., Alexander, P. A., \& Grossnickle, E. M. (2013). Relational reasoning and its manifestations in the educational context: A systematic review of the literature. Educational Pscyhology Review, 25(3), 391-427. doi:10.1007/s10648-013-9224-4

Edson, A. J., Phillips, E., Slanger-Grant, Y., \& Stewart, J. (2018). The arc of learning framework: An ergonomic resource for design and enactment of problem-based curriculum. International Journal of Educational Research, 1-12. doi:10.1016/j.ijer.2018.09.020

Edwards, S. (2015). Active learning in the middle grades: This article offers examples of developing students' participation as a central tenet of ideal middle level education that is intellectually active, socially active, and physically active. Middle School Journal, 46(5), 26-32. doi:10.1080/00940771.2015.11461922

Ferguson, A. M., Maloney, E. A., Fugelsang, J., \& Risko, E. F. (2015). On the relation between math and spatial ability: The case of math anxiety. Learning and Individual Differences, 39, 1-12. doi:10.1016/j.lindif.2015.02.007

Fonna, M., \& Mursalin, M. (2019). Using of wingeom software in geometry learning to improving the of mathematical representation ability. Malikussaleh Journal of Mathematics Learning (MJML), 1(2), 40-43. doi:10.29103/mjml.v1i2.1174

Fyfe, E. R., \& Brown, S. A. (2020). This is easy, you can do it! Feedback during mathematics problem solving is more beneficial when students expect to succeed. Instructional Science. doi:10.1007/s11251-019-09501-5

Ginting, A. S., Joebagio, H., \& Si, C. D. (2020). A needs analysis of history learning model to improve constructive thinking ability through scientific approach. International Journal of Education and Social Science Research, 3(1), 13-18.

Goldhaber, D., Krieg, J. M., \& Theobald, R. (2020). Exploring the impact of student teaching apprenticeships on student achievement and mentor teachers. Journal of Research on Educational Effectiveness, 1-22. doi:10.1080/19345747.2019.1698087

Hair, J. F., Black, W. C., Babin, B. J., \& Anderson, R. E. (2010). Multivariate data analysis. Upper Saddle River: Pearson Education, Inc.

Hansen, R. (2020). The use of learning goals in mathematics education. Scandinavian Journal of Educational Research, 1-13. doi:10.1080/00313831.2020.1739125

Hua, X., Tang, M., Sun, S., \& Han, Z. (2019, January). Inquiry into mathematics teaching in senior high school-taking "planar analytic geometry" as an example. In 3rd International Seminar on Education Innovation and Economic Management (SEIEM 2018). Atlantis Press. doi:10.2991/seiem-18.2019.81

Humble, S., \& Dixon, P. (2017). The effects of schooling, family and poverty on children's attainment, potential and confidence-evidence from kinondoni, dar es salaam, Tanzania. International Journal of Educational Research, 83, 94-106. doi:10.1016/j.ijer.2017.03.001

Julaihi, N. H., Ying, L. C., Li, V. L., \& Bakri, S. R. A. (2020). Confidence level and selfefficacy beliefs of mathematics teachers: evidence from Sarawak. International Journal of Service Management and Sustainability, 4(2), 1-23. doi:10.24191/ijsms.v4i2.8145 
Kaufmann, O. T. (2019). Students' reasoning on multiplication in primary school classroom context. Journal of Research in Mathematics Education, 8(1), 6-29. doi:10.17583/redimat.2019.2822

Kılıç, D., \& Sağlam, N. (2013). Students' understanding of genetics concepts: the effect of reasoning ability and learning approaches. Journal of Biological Education, 48(2), 6370. doi:10.1080/00219266.2013.837402

Kleitman, S., \& Gibson, J. (2011). Metacognitive beliefs, self-confidence and primary learning environment of sixth grade students. Learning and Individual Differences, 21(6), 728-735.

Kleitman, S., Stankov, L., Allwood, C. M., Young, S., \& Mak, K. K. L. (2012). Metacognitive self-confidence in school-aged children. In Self-directed Learning Oriented Assessments in the Asia-Pacific (pp. 139-153). Springer, Dordrecht. doi:10.1007/97894-007-4507-0_8

Kosko, K. W., \& Gao, Y. (2015). Mathematical communication in state standards before the common core. Educational Policy, 31(3), 275-302. doi:10.1177/0895904815595723

Lauer, J. E., \& Lourenco, S. F. (2016). Spatial processing in infancy predicts both spatial and mathematical aptitude in childhood. Psychological Science, 27(10), 1291-1298.

Lessani, A., Yunus, A., \& Bakar, K. (2017). Comparison of new mathematics teaching methods with traditional method. People: International Journal of Social Sciences, 3(2), 1285-1297. doi:10.20319/pijss.2017.32.12851297

Luguetti, C., Aranda, R., Nuñez Enriquez, O., \& Oliver, K. L. (2019). Developing teachers' pedagogical identities through a community of practice: Learning to sustain the use of a student-centered inquiry as curriculum approach. Sport, Education and Society, 24(8): 855-866.

Majid, N. A. A., \& Majid, N. A. (2018). Augmented reality to promote guided discovery learning for STEM learning. Journal on Advanced Science, Engineering and Information Technology, 8(4-2), 1494-1500.

Martin, L. C., \& Towers, J. (2015). Growing mathematical understanding through collective image making, collective image having, and collective property noticing. Educational Studies in Mathematics, 88(1), 3-18. doi:10.1007/s10649-0149552-4

Mayer, D., Sodian, B., Koerber, S., \& Schwippert, K. (2014). Scientific reasoning in elementary school children: Assessment and relations with cognitive abilities. Learning and Instruction, 29, 43-55. doi:10.1016/j.learninstruc.2013.07.005

Morrison, G. R., Ross, S. M., Kalman, H. K., \& Kemp, J. E. (2013). Designing effective instruction. Hoboken, NJ: John Wiley \& Sons, Inc.

Moschkovich, J. N. (2015). Scaffolding student participation in mathematical practices. ZDM Mathematics Education, 47(7), 1067-1078. doi:10.1007/s11858-015-0730-3

Murhayati, S., Hartono, Hertina, Yendra, R., Desvina, A. P., \& Fudholi, A. (2019). Spatial analysis for detect gender influence on score test English language and mathematics subjects junior high school in Pekanbaru. International Journal of Engineering and Advanced Technology (IJEAT), 8(3), 204-208.

Naseri, E. (2019). Comparing the impact of audio-visual input enhancement on collocation learning in traditional and mobile learning contexts. Applied Research on English Language, 8(3): 383-422.

National Council of Teachers of Mathematics (NCTM). (2014). Principles to actions: Ensuring mathematical success for all. Reston, VA: NCTM.

Norton, A., \& Alibali, M. W. (2018). Constructing number: Merging perspectives from psychology and mathematics education. Cham, Switzerland: Springer. 
Otten, S., Gilbertson, N. J., Males, L. M., \& Clark, D. L. (2014). The mathematical nature of reasoning-and-proving opportunities in geometry textbooks. Mathematical Thinking and Learning, 16(1), 51-79. doi:10.1080/10986065.2014.857802

Pallant, J. (2016). SPSS survival manual: A step by step guide to data analysis using SPSS for windows (version 12). Maidenhead: Open University Press.

Rogers, J., \& Révész, A. (2020). Experimental and quasi-experimental designs. The Routledge handbook of research methods in applied linguistics. New York: Routledge.

Ryve, A., Nilsson, P., \& Pettersson, K. (2013). Analyzing effective communication in mathematics group work: The role of visual mediators and technical terms. Educational Studies in Mathematics, 82(3), 497-514.

Shofiyati, A., Retnoningsih, A., \& Ridlo, S. (2020). Development of learning modules discovery learning models based on results of plant identification in school environments. Journal of Innovative Science Education, 9(1), 19-27. doi:10.15294/JISE.V8I1.32153

Siregar, N. C., Rosli, R., \& Maat, S. M. (2019). Development of the D-geometry module based on discovery learning. International Journal of Academic Research in Progressive Education and Development, 8(3), 99-109. doi:10.6007/IJARPED/v8i3/6290

Stankov, L., Kleitman, S., \& Jackson, S. A. (2015). Measures of the trait of confidence. In Measures of Personality and Social Psychological Constructs (pp. 158-189). Academic Press. doi:10.1016/B978-0-12-386915-9.00007-3

Stankov, L., Lee, J., Luo, W., \& Hogan, D. J. (2012). Confidence: A better predictor of academic achievement than self-efficacy, self-concept and anxiety? Learning and Individual Differences, 22(6), 747-758. doi:10.1016/j.lindif.2012.05.013

Suantoa, E., Zakaria, E., \& Maat, S. M. (2019). The development of the KARA module based on experiential learning approaches in the threedimensional geometry blocks topic for lower secondary school students. International Journal of Innovation, Creativity and Change, 7(11), 26-46.

Tabach, M., \& Nachlieli, T. (2016). Communicational perspectives on learning and teaching mathematics: Prologue. Educational Studies in Mathematics, 91(3), 299-306. doi: 10.1007/s10649-015-9638-7

Von Glaserfield, E. (1989). Constructivism in education. In. Husen, T. and Postlewaite (Ed.). International Encyclopedia of Education. Oxford, England: Pergamon Press.

Voyer, D., Voyer, S. D., \& Saint-Aubin, J. (2017). Sex differences in visual-spatial working memory: A meta-analysis. Psychonomic Bulletin \& Review, 24(2), 307-334. doi:10.3758/s13423-016-1085-7

Wachidi, W., Rodgers, A., \& Tumanov, D. Y. (2020). Professional competence understanding level of elementary school in implementing curriculum 2013. International Journal of Educational Review, 2(1), 99-105.

Wolfe, M. J. (2019). Smart girls traversing assemblages of gender and class in Australian secondary mathematics classrooms. Gender and Education, 31(2), 205-221. doi:10.1080/09540253.2017.1302078 